\title{
Bacterial influences on Atlantic halibut Hippoglossus hippoglossus yolk-sac larval survival and start-feed response
}

\author{
David W. Verner-Jeffreys ${ }^{1,3}$, Robin J. Shields ${ }^{2,4}$, T. Harry Birkbeck ${ }^{1, *}$ \\ ${ }^{1}$ Institute of Biomedical and Life Sciences, Division of Infection and Immunity, Joseph Black Building, University of Glasgow, \\ Glasgow G12 8QQ, UK \\ ${ }^{2}$ Seafish Aquaculture, Ardtoe, Argyll PH36 4LD, UK \\ ${ }^{3}$ Present address: CEFAS Laboratory, The Nothe, Weymouth, Dorset DT4 8UB, UK \\ ${ }^{4}$ Present address: Aquaculture Wales, University of Wales, Swansea, Singleton Park, Swansea SA2 8PP, UK
}

\begin{abstract}
A bacteria-free halibut larval rearing system was used to test 20 bacterial isolates, from British halibut hatcheries, for their toxicity towards halibut yolk-sac larvae under microbially controlled conditions. The isolates tested spanned a range of genera and species (Pseudoalteromonas, Halomonas marina, Vibrio salmonicida-like, Photobacterium phosphoreum and V. splendidus species). A pathogen of turbot, Scophthalmus maximus, V. anguillarum 91079, and 2 isolates from adult halibut were also included. Isolates were inoculated, at a concentration of $5 \times 10^{2} \mathrm{cfu} \mathrm{ml}^{-1}$, into flasks containing 25 recently hatched axenic halibut larvae, using a minimum of 3 flasks for each treatment. Control survivals to $38 \mathrm{~d}$ post-hatch for the 3 experiments averaged $84,51.5$ and $49 \%$, respectively. With the exception of $V$. anguillarum 91079, which was highly pathogenic towards halibut yolk-sac larvae, there was no statistically significant difference in survival between the controls and the different treatments. This suggests that most of the bacteria routinely isolated from halibut hatcheries are not harmful to yolk-sac larvae, even though most flasks contained in excess of $5 \times 10^{6} \mathrm{cfu} \mathrm{ml}^{-1}$ of the inoculated organism when the experiments were terminated. Three organisms previously shown to inhibit growth of bacteria in vitro were tested for their ability to protect halibut yolk-sac larvae against invasion by $V$. anguillarum. In 4 separate challenge experiments none of the test isolates, a Pseudoalteromonas strain and 2 Carnobacterium-like organisms, showed any protective effect. To investigate how particular bacteria influence their start-feed response, larvae were fed axenic and gnotobiotic Artemia colonized with a range of different Vibrio spp., and examined after $8 \mathrm{~d}$. There were no statistically significant between-treatment differences in the proportion of Artemia-containing larvae, indicating that bacterial contamination of the live food does not appear to influence initiation of the feeding response.
\end{abstract}

KEY WORDS: Halibut larvae $\cdot$ Bacteria $\cdot$ Probiotic $\cdot$ Vibrio anguillarum

Resale or republication not permitted without written consent of the publisher

\section{INTRODUCTION}

Atlantic halibut are unique among commercially reared marine fish in having a long larval yolk-sac stage following hatching (>35 d), when they are wholly reliant on endogenous reserves (Haug 1990). Under current UK hatchery protocols, halibut eggs are hatched in situ in large (>500 l) upwelling silos and the hatched yolk-sac larvae are reared in the dark at a low temperature $\left(<6^{\circ} \mathrm{C}\right)$, for at least $2 / 3$ of the yolk-sac absorption phase. They are then transferred to illuminated first-feeding tanks where the temperature is raised to $10-12^{\circ} \mathrm{C}$, and are presented with live prey (Artemia or marine copepods) (Shields et al. 1999).

In the UK, mortalities through these initial phases are often high; on average less than $50 \%$ of hatched larvae survive the yolk-sac absorption period. Of the survivors, frequently less than $20 \%$ initiate a feeding response and the remainder consequently starves to death (Shields et al. 1999). 
The specific causes of the high mortalities are unclear, as both the variation in survival and first-feed response from tank to tank can be high. It has been postulated that this variable survival is due to opportunistic pathogens able to take advantage of high densities of hosts of reduced immunocompetence (Hansen \& Olafsen 1999, Ringo \& Birkbeck 1999, Skjermo \& Vadstein 1999). There is indirect evidence that bacteria have a role in larval mortalities, in that addition of antibiotics such as oxytetracycline enhances survival of yolk-sac larvae reared in small-scale static systems (Lein et al. 1997, Ottesen \& Bolla 1998). Also, addition of antibiotics has been shown to improve survival in commercial-scale incubators and to reduce tank-to-tank variation in their survival (Verner-Jeffreys 2000). Although pathogens such as Vibrio anguillarum, Flexibacter ovolyticus and Aeromonas salmonicida ssp. salmonicida can cause mortalities in experimentally reared larvae (Bergh et al. 1992, 1997), it is unclear which of the bacteria, other than F. ovolyticus, occurring in commercial rearing systems for Atlantic halibut larvae are harmful, as $V$. anguillarum and $A$. salmonicida are rarely isolated from such tanks.

To test the hypothesis that bacteria affect halibut yolk-sac larval performance, the effect of individual bacterial isolates, originally isolated from commercial rearing systems, on larval survival was tested under bacterially defined conditions.

Adverse bacterial floras in rearing systems may be controlled by addition of probiotic organisms which colonize the gut of developing larvae and prevent colonization by pathogenic micro-organisms (Gatesoupe 1999, Hansen \& Olafsen 1999, Ringo \& Birkbeck 1999, Skjermo \& Vadstein 1999). Therefore, in conjunction with the above experiments with bacterially defined small-scale rearing systems, the potential of 3 organisms, previously shown to inhibit growth of bacteria in vitro, were tested for their ability to protect halibut yolk-sac larvae against invasion by the pathogen Vibrio anguillarum. Also, to test whether high levels of bacteria commonly associated with the live prey inhibit the start-feed response in halibut larvae we offered such larvae Artemia colonized with defined bacteria to investigate how specific bacteria influence the start-feed response.

\section{MATERIALS AND METHODS}

Bacteria. The bacterial isolates used in this study are shown in Table 1. The 26 isolates shown include 22 tested for their effects on larvae (see Table 2) and 4 which were only tested in first-feeding experiments. Bacteria were routinely grown in shake cultures of marine broth (MB, Difco) or on marine agar (MA, marine broth plus $1.5 \%$ technical agar) at $15^{\circ} \mathrm{C}$. For long-term storage cultures were stored using the Protect system (Technical Service Consultants) at $-70^{\circ} \mathrm{C}$, according to the manufacturer's instructions except that $100 \mu \mathrm{l} 20 \% \mathrm{NaCl}$ was added to the culture medium to raise the salinity.

Supply and preparation of halibut eggs for infection experiments. Eggs were collected from a commercial hatchery after incubation at $5^{\circ} \mathrm{C}$ for $13 \mathrm{~d}(65$ degree-days post-fertilization). All the eggs (approx. 1 1) from a conical incubator were removed and treated with a solution of $8 \mathrm{ml}$ of $25 \%$ glutaraldehyde (Sigma) in 51 of $100 \mu \mathrm{m}$ filtered, UV-sterilized hatchery water for $10 \mathrm{~min}$ (glutaraldehyde working concentration $0.125 \% \mathrm{v} / \mathrm{v})$. Eggs were then rinsed thoroughly in seawater (SW) from the same source. Some eggs were transferred to 21 stoppered conical flasks containing $1.5 \mathrm{l}$ of seawater and antibiotics (oxolinic acid, kanamycin and erythromycin (Sigma), all at 0.01 $\mathrm{g} \mathrm{l}^{-1}$; penicillin $\mathrm{G}, 0.15 \mathrm{~g} \mathrm{l}^{-1}$; streptomycin, $0.075 \mathrm{~g} \mathrm{l}^{-1}$ ) added. The eggs were transported on ice in antibiotic-containing flasks, normally within $2 \mathrm{~h}$ of collection, to a controlled environment room in our laboratory. After overnight incubation, eggs were rinsed in sterile seawater (SSW), treated for $20 \mathrm{~s}$ in $0.02 \%$ peracetic acid-based solution (Kick Start; RS Hygiene) and rinsed again in SSW; 25 eggs were then distributed into each 21 conical flask containing 1.51100 $\mu \mathrm{m}$ filtered $32 \%$ hatchery SW. The SW was allowed to mature for at least $2 \mathrm{wk}$ prior to distribution into flasks stoppered with compressed paper plugs (Fisher Scientific), sterilization by autoclaving and equilibration to $6^{\circ} \mathrm{C}$.

Single strain addition infection Expts 1 to 3. All bacterial isolates were incubated overnight in $\mathrm{MB}$ shake cultures at $15^{\circ} \mathrm{C}$. Bacteria were collected by centrifugation, washed 3 times in $25 \%$ artificial seawater (ASW) before estimation of bacterial concentrations by spectrophotometry, based on an optical density $(\mathrm{OD})_{650 \mathrm{mn}}$ reading of 1.0 being equivalent to $10^{9}$ bacteria $\mathrm{ml}^{-1}$. For Expts 1 to 3, washed cultures were added to the experimental flasks 3 to $5 \mathrm{~d}$ after the eggs hatched, to give final bacterial cell densities of $5 \times$ $10^{2}$ cells $\mathrm{ml}^{-1}$.

Experiments with probiotic bacteria: infection Expts 4 to 6. Three potential probiotic candidates were tested in 3 further rearing experiments for their ability to protect halibut yolk-sac larvae against infection by Vibrio anguillarum: these were a Pseudoalteromas species, TG15-07, and 2 Gram-positive Carnobacterium isolates, AN1 and AN2. These isolates had previously been shown to inhibit the growth of many other bacteria including the pathogen $\mathrm{V}$. anguillarum 91079, in vitro following standard meth- 
Table 1. Bacterial isolates used in this study. The rearing trial investigated the effects of halibut yolk-sac rearing conditions on larval survival and gut flora development (Treatment F: flow-to-waste with disinfected eggs; Treatment RD: recirculated water with disinfected eggs; Treatment RN: recirculated water with non-disinfected eggs [Verner-Jeffleys 2000]). The survey investigated the types of bacteria associated with Atlantic halibut in UK hatcheries (Verner-Jeffreys et al. 2003). All isolates were Gram-negative rods, except for AN1 and AN2. Characterization followed the scheme of Verner-Jeffreys et al. (2003), except for Phenons 4 to 7 and where otherwise described. Isolates assigned to Phenons 4 to 7 were genetically and biochemically distinct groups of Gram-negative organisms not reported in the survey (Verner-Jeffreys 2000)

\begin{tabular}{|c|c|c|}
\hline Isolate & Source & $\begin{array}{l}\text { Description (and EMBL accession } \\
\text { number for partial } 16 \mathrm{~S} \text { rDNA sequence } \\
\text { where available) }\end{array}$ \\
\hline SYS6-10 & Survey; healthy yolk-sac larvae & Vibrio sp. \\
\hline TG2-11 & $\begin{array}{l}\text { Rearing trial, Treatment F; poorly performing } \\
\text { yolk-sac larva }\end{array}$ & $\begin{array}{l}\text { Fermentative, catalase-positive, } \\
\text { oxidase-negative (Phenon 5) }\end{array}$ \\
\hline TG2-12 & $\begin{array}{l}\text { Rearing trial, Treatment } F_{\text {; }} \text { poorly performing } \\
\text { yolk-sac larvae }\end{array}$ & $\begin{array}{l}\text { Weakly fermentative, oxidase-negative } \\
\text { (Phenon 4) }\end{array}$ \\
\hline TG2-14 & $\begin{array}{l}\text { Rearing trial, Treatment } F_{;} \text {poorly performing } \\
\text { yolk-sac larvae }\end{array}$ & $\begin{array}{l}\text { Fermentative, oxidase-negative } \\
\text { (Phenon 4) }\end{array}$ \\
\hline TG2-18 & Rearing trial, Treatment $F_{\text {; }}$ poorly performing larvae & Oxidase-negative (Phenon 7) \\
\hline TG4-02 & Rearing trial, Treatment $\mathrm{RN}_{\text {; }}$ healthy yolk-sac larvae & Vibrio splendidus gp. 3 \\
\hline TG4-07 & Rearing trial, Treatment RN; healthy yolk-sac larvae & Vibrio splendidus gp. 3 (AJ414125) \\
\hline TG4-11 & Rearing trial, Treatment $\mathrm{RN}_{\text {; }}$ healthy yolk-sac larvae & Pseudoalteromonas sp. (Phenon 3) \\
\hline TG7-01 & Rearing trial, Treatment $F$; poorly performing larvae & $\begin{array}{l}\text { Oceanospirillum-like; weakly } \\
\text { fermentative (Phenon 6) (AJ414130) }\end{array}$ \\
\hline TG8-01 & Rearing trial, Treatment RD; healthy yolk-sac larvae & Pseudoalteromonas gp. 3 (AJ414131) \\
\hline TG10-01 & Rearing trial, Treatment $F_{;}$healthy yolk-sac larvae & Pseudoalteromonas gp. 1 \\
\hline TG11-16 & Rearing trial, Treatment RD; healthy yolk-sac larvae & Pseudoalteromonas gp. 3 \\
\hline TG15-07 & Rearing trial, Treatment RN; healthy yolk-sac larvae & $\begin{array}{l}\text { Pseudoalteromonas gp. } 4 \text { (AJ318941). } \\
\text { Strongly inhibits growth of other } \\
\text { bacteria in vitro }\end{array}$ \\
\hline TG15-08 & Rearing trial, Treatment RD; healthy yolk-sac larvae & Pseudoalteromonas gp. 2 \\
\hline TG15-19 & Rearing trial, Treatment RD; healthy yolk-sac larvae & Pseudoalteromonas gp. 3 \\
\hline TG16-05 & Rearing trial, Treatment RD; healthy yolk-sac larvae & $\begin{array}{l}\text { Oceanospirillum-like, weakly } \\
\text { fermentative, oxidase-negative } \\
\text { (Phenon 6) (AJ41426) }\end{array}$ \\
\hline Vibrio anguillarum 91079 & Moribund juvenile turbot & Horne et al. (1977) \\
\hline AE1-26 & Survey; enriched Artemia (A318954) & Hemolytic Vibrio splendidus gp. 1 \\
\hline OFE1-19 & Survey; halibut eggs & RFLP group VII \\
\hline E1-03 & Survey; freshly fertilized halibut eggs & Photobacterium phosphoreum \\
\hline AN1 & Adult turbot gut from survey & $\begin{array}{l}\text { Carnobacterium sp., inhibiting growth } \\
\text { of bacteria in vitro }\end{array}$ \\
\hline AN2 & Adult turbot gut from survey & $\begin{array}{l}\text { Carnobacterium sp., inhibiting growth } \\
\text { of bacteria in vitro }\end{array}$ \\
\hline OF2-05 & $\begin{array}{l}\text { Survey; healthy first-feeding halibut maintained on } \\
\text { calanoid copepod diet }\end{array}$ & Vibrio salmonicida-like (AJ318950) \\
\hline AF6-01 & $\begin{array}{l}\text { Survey; moribund first-feeding halibut larvae } \\
\text { maintained on Artemia }\end{array}$ & Photobacterium phosphoreum \\
\hline AF2-14 & $\begin{array}{l}\text { Survey; first-feeding halibut larvae maintained } \\
\text { on Artemia }\end{array}$ & $\begin{array}{l}\text { Hemolytic Vibrio splendidus gp. } 1 \\
\text { (AJ414123) }\end{array}$ \\
\hline DMC-1 & $\begin{array}{l}\text { Pathogen isolated from moribund larval turbot } \\
\text { in commercial Spanish turbot }\end{array}$ & Hemolytic Vibrio splendidus \\
\hline OF1-02 & $\begin{array}{l}\text { Survey; first-feeding halibut larvae maintained on } \\
\text { mixed Artemia and copepod diet }\end{array}$ & $V$. alginolyticus \\
\hline
\end{tabular}

ods (Smith \& Davey 1993, Gram et al. 1999). Isolates were incubated and harvested as described above, with the exception of AN1 and AN2, which were incubated for 2 to $3 \mathrm{~d}$ in static Tryptose Soya Broth (Oxoid) $+2 \% \mathrm{NaCl}+1 \%$ glucose cultures at $20^{\circ} \mathrm{C}$.
For infection Expt 4, strains AN1, AN2 and TG15-07 were tested. Pseudoalteromonas TG15-07 was added to larvae once to a final concentration of $5 \times 10^{5} \mathrm{cfu}$ $\mathrm{ml}^{-1}$. For AN1 and AN2 treatments, both isolates were added 3 times, at Days 1, 4 and 10 post hatch, to a final 
concentration of $1 \times 10^{6} \mathrm{cfu} \mathrm{ml}^{-1}$. The larvae were then challenged with Vibrio anguillarum at $1 \times 10^{3} \mathrm{cfu} \mathrm{m}^{-1}$ 3 d later. Appropriate controls were also included (TG15-07, AN1 and AN2 added alone, V. anguillarum alone, and no bacteria added). Four replicate flasks were used for each treatment.

For Expt 5, TG15-07 was added to larvae at 2 concentrations $1 \mathrm{~d}$ post hatch, $1 \times 10^{2}$ and $5 \times 10^{5} \mathrm{cfu}$ $\mathrm{ml}^{-1}$. The larvae were challenged with Vibrio anguillarum at $1 \mathrm{cfu} \mathrm{ml}^{-1} 3 \mathrm{~d}$ later. Appropriate controls were also included (TG15-07 added alone at the 2 concentrations, $V$. anguillarum alone and no bacteria added). Four replicate flasks were used for each treatment.

In Expt 6, isolates AN1 and AN2 were tested with a lower Vibrio anguillarum inoculum than in Expt 4. Each probiotic candidate was added as described for Expt 4, and $V$. anguillarum was added to the test flasks $4 \mathrm{~d}$ post hatch to a concentration of $10 \mathrm{cfu} \mathrm{ml}^{-1}$. Appropriate controls (AN1, AN2 and $V$. anguillarum alone, or no bacteria added) were again included. Four replicate flasks were again used for each treatment.

Maintenance of yolk-sac larvae. For all experiments, flasks were maintained in the dark at 5.5 to $6.0^{\circ} \mathrm{C}$ for 30 to $42 \mathrm{~d}$. At the end of the incubation period surviving larvae in all flasks were counted. The control flasks, where no bacteria were added, were assessed for bacteriological sterility by direct plating of $100 \mu \mathrm{l}$ water samples onto MA and addition of $5 \mathrm{ml}$ water to $5 \mathrm{ml}$ MB. Selected control flasks were also analyzed for the presence of bacteria not culturable on MA by microscopic examination of glutaraldehyde-fixed 4', 6diamidino-2-phenylindole (DAPI)-stained water samples as described elsewhere (Enger et al. 1989). For flasks inoculated with bacteria, serial 10-fold dilutions of water samples were made in $25 \%$ ASW and $100 \mu \mathrm{l}$ plated onto MA in duplicate. Viable counts were made after $4 \mathrm{wk}$ incubation at $6^{\circ} \mathrm{C}$ to calculate the average final flask density of bacteria for each treatment.

Effect of bacterial isolates on the start feed response: infection Expts 7 to 8. The effect of bacterial isolates on the start feed response was investigated using the flask-rearing model in 2 experiments, infection Expts 7 and 8 . The system used was not bacteria-free, although live food and eggs were treated to remove bacteria. Twenty-five disinfected eggs were placed into 21 flasks and hatched larvae reared as previously described until Day 35, except for an $80 \%$ water exchange at Day 28. At this point the flasks were transferred to a separate controlled environment room where the temperature was gradually raised from 6 to $9^{\circ} \mathrm{C}$ over $4 \mathrm{~d}$. At this point (approximately $40 \mathrm{~d}$ post hatch) light from a fluorescent source was provided in the controlled environment room, and Pavlova lutheri was added to each flask to a final density of $3.5 \times 10^{3}$ cells $\mathrm{ml}^{-1}$. P. lutheri were cultured as described previously (Munro et al. 1995), except that the cultures used were not free of bacteria, containing some which were culturable on MA but not on Thiosulphate Citrate Bile Salt Sucrose agar (TCBS, Difco). Visual assessment of the number of living halibut larvae in each flask was made prior to addition of 750 monoxenic or axenic freshly hatched Artemia, to each flask.

Preparation of monoxenic Artemia. Decapsulation to remove the external chorions from Artemia cysts under axenic conditions was done as follows. Initially, cysts (EG grade cysts, INVE Aquaculture) were rehydrated in aerated distilled water for $1 \mathrm{~h}$, before collection on a 6 sterile $100 \mu \mathrm{m}$ sieve followed immediately by immersion in alkaline $10 \%$ sodium hypochlorite solution in $0.25 \mathrm{M}$ $\mathrm{NaOH}$ over ice. The solution was kept on ice and stirred with a sterile glass rod until the outer chorion had dissolved, as indicated by the colour of the cysts turning from brown through white to orange. The reaction was then quenched by addition of $0.1 \mathrm{M} \mathrm{HCl}$. The cysts were rinsed thoroughly in sterile seawater and approximately $0.3 \mathrm{~g}$ amounts of the decapsulated cysts were distributed into sterile containers for later use. Decapsulated cysts were used within $1 \mathrm{wk}$ of preparation. When required, decapsulated cysts were hatched overnight in stoppered 21 flasks containing sterile SW aerated with $0.22 \mu \mathrm{m}$ filtered air supplied to each flask under conditions of high light intensity. After $24 \mathrm{~h}$ the Artemia nauplii were collected on a sterile $100 \mu \mathrm{m}$ filter, the concentration adjusted to 10 nauplii $\mathrm{ml}^{-1}$ and the nauplii dispensed into separate sterile, stoppered, $100 \mathrm{ml}$ Erlenmeyer flasks. Individual bacterial strains to be tested were grown overnight and harvested as previously described, before addition to the separate flasks to a final concentration of $5 \times 10^{5} \mathrm{cfu} \mathrm{m}^{-1}$ in each case. Artemia and bacteria were incubated together for a minimum of $2 \mathrm{~h}$ prior to adding 750 Artemia nauplii to each of the specified treatment flasks (0.5 Artemia ml ${ }^{-1}$ ). Larvae were fed on 4 further occasions with axenic Artemia before termination of the experiments after $8 \mathrm{~d}$. No water exchange was attempted during this period. At this point, all larvae were anaesthetised by immersion in $0.1 \%(\mathrm{w} / \mathrm{v})$ benzocaine in SW for $30 \mathrm{~s}$ and assessed for the 24 presence of Artemia in their guts, by observation under a binocular dissecting microscope. All 25 larvae were then fixed in buffered formol saline. Water samples from each flask were plated onto MA and TCBS. Water quality parameters (ammonia, nitrate and nitrate concentrations) were assessed using aquarium test kits (Tetra Werke).

Data analysis. Survivals in the different treatments were analyzed by comparing numbers of larvae present in the control, uninfected flasks, and the infected flasks using Mann-Whitney tests. Analysis was done on a PC using the program Minitab v13 (Minitab Ltd.). 
Table 2. Hippoglossus hippoglossus. Effect of specific bacteria on the survival of Atlantic halibut yolk-sac larvae. In Expt 1, all control flasks were apparently sterile (as assessed by both DAPI staining of water samples and inoculation into marine broth, $\mathrm{MB}$ ). In Expt 2, 7 out of 8 control flasks were free of marine agar (MA)-culturable organisms. DAPI staining of these water samples showed $3 / 7$ contained $>10^{5} \mathrm{cfu} \mathrm{ml}^{-1}$ rod-shaped bacteria. In Expt 3 all control flasks were contaminated and by inference most other flasks were probably also contaminated. It should not be concluded that the final bacterial density in those flasks was dominated by the bacterial inoculates. ND: no data

\begin{tabular}{|c|c|c|c|c|c|}
\hline Expt & $\begin{array}{l}\text { Length of } \\
\text { experiment }(\mathrm{d})\end{array}$ & Treatment & $\begin{array}{l}\text { of flasks } \\
\text { treatment }\end{array}$ & $\begin{array}{l}\text { Mean \% survival } \\
\quad( \pm \text { SEM })\end{array}$ & $\begin{array}{l}\text { Bacteria density at end of experiment } \\
\text { Mean cfu } \mathrm{ml}^{-1} \pm \text { SEM }\end{array}$ \\
\hline 1 & 34 & $\begin{array}{l}\text { None } \\
\text { SYS6-10 } \\
\text { TG11-16 } \\
\text { TG15-07 } \\
\text { TG4-07 } \\
\text { TG7-01 }\end{array}$ & $\begin{array}{l}3 \\
4 \\
3 \\
3 \\
5 \\
4\end{array}$ & $\begin{array}{c}84( \pm 9.8) \\
41( \pm 10.7) \\
52( \pm 12.2) \\
41.3( \pm 14.5) \\
57.6( \pm 11.6) \\
64( \pm 19.1)\end{array}$ & $\begin{array}{c}<1 \\
6.1 \times 10^{6} \pm 9.8 \times 10^{5} \\
>1 \times 10^{6} \\
5.7 \times 10^{6} \pm 1.9 \times 10^{5} \\
1.6 \times 10^{6} \pm 4.0 \times 10^{5} \\
2.9 \times 10^{6} \pm 1.5 \times 10^{6}\end{array}$ \\
\hline 2 & 38 & $\begin{array}{l}\text { Control } \\
\text { AE1-26 } \\
\text { TG10-01 } \\
\text { TG15-19 } \\
\text { TG16-05 } \\
\text { TG2-14 } \\
\text { TG2-18 } \\
\text { TG4-02 } \\
\text { TG8-01 }\end{array}$ & $\begin{array}{l}8 \\
4 \\
4 \\
4 \\
4 \\
4 \\
4 \\
4 \\
4\end{array}$ & $\begin{array}{c}49( \pm 14) \\
45( \pm 5.4) \\
60( \pm 10.2) \\
20( \pm 9.5) \\
49( \pm 2.8) \\
55( \pm 8.2) \\
45( \pm 10.6) \\
83( \pm 15.7) \\
47( \pm 15.6)\end{array}$ & $\begin{array}{c}<1 \\
4.8 \times 10^{6} \pm 3.2 \times 10^{6 a} \\
9.1 \times 10^{5} \pm 1.1 \times 10^{6} \\
2.5 \times 10^{7} \pm 7.9 \times 10^{6} \\
2.0 \times 10^{6} \pm 1.26 \times 10^{6} \\
9.1 \times 10^{5} \pm 1.1 \times 10^{6} \\
1.2 \times 10^{7} \pm 3.6 \times 10^{6} \\
1.4 \times 10^{7} \pm 6.2 \times 10^{6} \\
1.7 \times 10^{7} \pm 1.0 \times 10^{7}\end{array}$ \\
\hline 3 & 38 & $\begin{array}{c}\text { None } \\
\text { ibrio anguillarum } \\
91079 \\
\text { El-03 } \\
\text { OFE1-19 } \\
\text { OFE1-05 } \\
\text { TG15-08 } \\
\text { TG2-11 } \\
\text { TG2-12 } \\
\text { TG4-11 }\end{array}$ & $\begin{array}{l}7 \\
4 \\
4 \\
4 \\
4 \\
4 \\
4 \\
4 \\
4\end{array}$ & $\begin{array}{c}51.5( \pm 7.8) \\
0^{\mathrm{b}} \\
43( \pm 11.8) \\
47( \pm 5.7) \\
47( \pm 13.3) \\
52( \pm 1.6) \\
50( \pm 12.1) \\
34( \pm 18) \\
27( \pm 9.3)\end{array}$ & $\begin{array}{c}>10^{6} \text { in all flasks } \\
\quad>10^{6} \\
>10^{6} \\
>10^{6} \\
>10^{6} \\
>10^{6} \\
>10^{6} \\
>10^{6} \\
>10^{6}\end{array}$ \\
\hline 4 & $\begin{array}{r}34 \\
\text { AN1 }+ \\
\text { AN2 + } \\
\text { TG15-07 } \\
V i\end{array}$ & $\begin{array}{c}\text { AN1 } \\
+ \text { Vibrio anguillarum } \\
\text { AN2 } \\
+ \text { Vibrio anguillarum } \\
\text { TG15-07 } \\
7+\text { Vibrio anguillarum } \\
\text { ibrio anguillarum }\end{array}$ & $\begin{array}{l}5 \\
5 \\
5 \\
5 \\
5 \\
5 \\
5\end{array}$ & $\begin{array}{c}31.2( \pm 9.8) \\
0 \\
32.0( \pm 9.7) \\
0 \\
22.4( \pm 8.1) \\
0 \\
8( \pm 8.9)\end{array}$ & $\begin{array}{l}\text { ND } \\
\text { ND } \\
\text { ND } \\
\text { ND } \\
\text { ND } \\
\text { ND } \\
\text { ND }\end{array}$ \\
\hline \multicolumn{6}{|c|}{$\begin{array}{l}{ }^{a} \text { Two of the } 4 \text { flasks to which AE1-26 was added were apparently free of TCBS- and MA-culturable bacteria; in the other two, } \\
\text { presumptive AE1-26 was present at high density }\left(>10^{7} \mathrm{cfu} \mathrm{ml}^{-1}\right) \\
\text { b Survival of larvae in flasks inoculated with Vibrio anguillarum } 91079 \text { was significantly lower than in the control (Mann- } \\
\text { Whitney; p < 0.05) }\end{array}$} \\
\hline
\end{tabular}

\section{RESULTS}

\section{Single strain addition infection experiments (Expts 1 to 3)}

Table 2 summarizes the results of testing Vibrio anguillarum and 20 bacterial strains isolated from halibut of varying developmental stages from UK hatcheries (Verner-Jeffreys 2000, Verner-Jeffreys et al. 2003) for their toxicity towards halibut yolk-sac larvae in 3 separate rearing experiments in the gnotobiotic 21 flask-rearing system. To illustrate the flask-to-flask variability in survival, Fig. 1 shows the results for individual flasks for the third experiment.

Unlike Vibrio anguillarum 91079, none of the 20 isolates from halibut rearing were significantly pathogenic, including organisms recovered from poorly performing larvae in rearing trials, a luminescent Photobacterium phosphoreum isolate E1-03, originally isolated from halibut eggs, or a hemolytic $V$. splendidus strain, AE1-26, originally isolated from Artemia cultures in a UK halibut hatchery. The experimental system generally produced a high proportion of halibut yolk-sac larvae free of culturable 


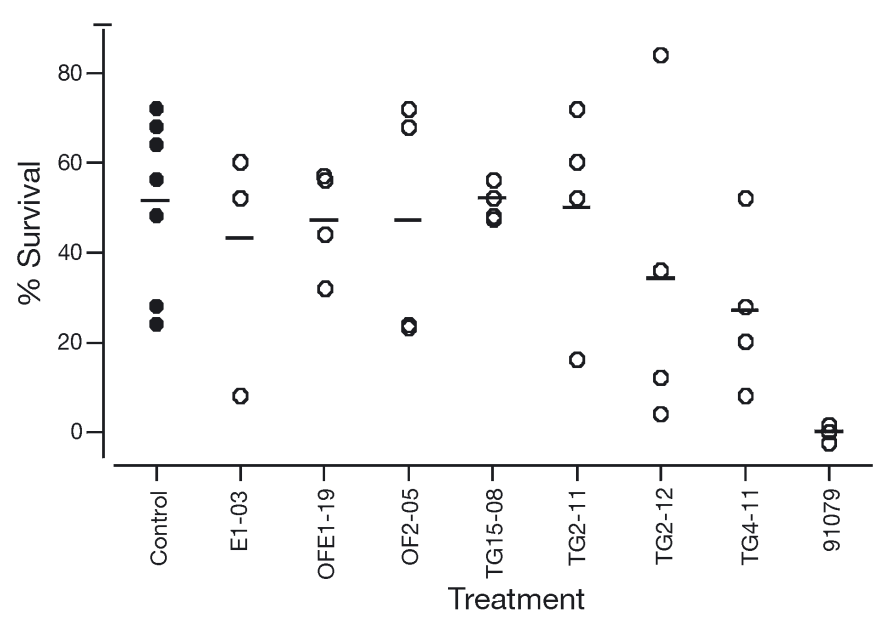

Fig. 1. Hippoglossus hippoglossus. Effect of addition of specific bacteria to yolk-sac larvae, illustrating intra-treatment variation. All flasks were stocked with 25 axenic halibut eggs; $5 \mathrm{~d}$ later they were inoculated with $5 \times 10^{2} \mathrm{cfu} \mathrm{m}^{-1}$ of a range of bacteria isolated from halibut-rearing systems. Individual survivals to $38 \mathrm{~d}$ post hatch for all the treatment flasks are shown; horizontal lines indicate the treatment averages. For this experiment, control flasks had no bacteria added; however, they were all contaminated by the end of the experiment with a range of Gram-negative organisms

bacteria. Control flasks in Expts 1 and 2 were almost all free of culturable bacteria immediately before addition of test bacteria, and similar results have been achieved in other rearing experiments not reported here. In Expt 3, high numbers of bacteria were found in all control flasks (Table 2). However, these results are included as the contaminating bacteria appeared to have no deleterious effect with the percentage survival in control flasks being similar to those in Expts 1 and 2.

It is clear that Vibrio anguillarum 91079 is highly pathogenic to halibut yolk-sac larvae at the low infection level used in Expt $2\left(5 \times 10^{2} \mathrm{ml}^{-1}\right)$. No larvae survived in any of the flasks infected with $V$. anguillarum, whether contaminating bacteria were present or not; the difference in survival in $V$. anguillarum-infected flasks was significant, compared to the non-infected controls (Mann-Whitney; p < 0.05). Levels of $V$. anguillarum free-living in the flask water were lower than the levels of contaminating organisms in 3 of the flasks. In one flask, $V$. anguillarum concentration was below the detection limit. Living yolk-sac larvae were present in all $V$. anguillarum-infected flasks 29 d after hatching (approximately 150 degree-days post infection), indicating a slow pathogenic process at this low incubation temperature $\left(6^{\circ} \mathrm{C}\right)$.

\section{Probiotic addition infection experiments (Expts 4 to 6)}

In a further series of trials, 3 bacterial strains (AN1, AN2, and TG15-07) which inhibited growth of Vibrio anguillarum in vitro were tested for their ability to protect against $V$. anguillarum in vivo. Table 2 shows that in all treatments where the test probiotic bacteria were added in conjunction with $10^{3} \mathrm{cfu} \mathrm{ml}^{-1} \mathrm{~V}$. anguillarum 91079, no larvae were alive by Day 34 (Expt 4). By contrast, surviving larvae were present in all the control flasks, where only the test probiotic bacteria or no other bacteria were added. There were significant differences in survival between the $V$. anguillaruminfected and other treatments, even between the controls and the flasks that were only infected with $V$. anguillarum, which had larvae surviving in 1 flask at the end of the experiment (Mann-Whitney; $\mathrm{p}<0.05$ ). Fig. 2 shows the cumulative mortality for the TG15-07 plus $V$. anguillarum, $V$. anguillarum alone and control treatments in Expt 4. A similar pattern was also seen for the AN1 and AN2 treatments (data not shown). Although larvae exposed to TG15-07 + V. anguillarum appeared to die faster than those that were only exposed to $V$. anguillarum alone, the difference was not significant. In this experiment larvae in 3 of 5 flasks were all dead by Day 20, but in the other 2 flasks larvae survived for longer.

In 2 further trials the concentration of Vibrio anguillarum was reduced to $1-10 \mathrm{cfu} \mathrm{ml}^{-1}$ to determine whether the putative probiotics could protect larvae from very low levels of challenge bacteria. However, larval survivals in the control flasks to which only $V$. anguillarum had been added were similar to those of

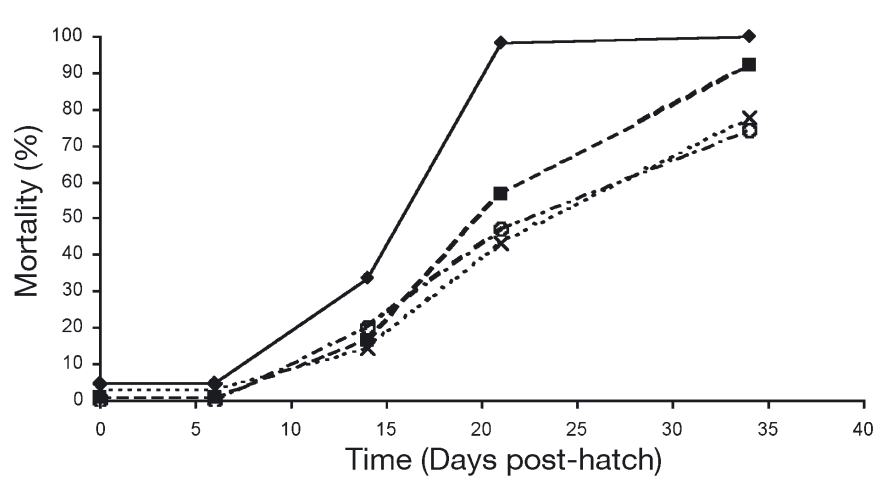

Fig. 2. Hippoglossus hippoglossus. Cumulative mortality of halibut yolk-sac larvae following challenge with $1 \times 10^{3} \mathrm{cfu}$ $\mathrm{ml}^{-1}$. Vibrio anguillarum 91079 Day 5 post hatch, in the presence or absence of TG15-07, a bacterial strain that inhibits 91079 in vitro. Mean cumulative mortality for each group is shown until 35 d post hatch $( \pm$ SEM). Each treatment consisted of 5 replicate flasks, individually stocked with 25 axenic halibut eggs. TG15-07 $+V$. anguillarum $(\bullet), V$. anguillarum (घ), TG15-07 only $(\times)$, Control (o) 
the other treatments. This indicated that the lethal dose (LD) ${ }_{50}$ for $V$. anguillarum 91079 in the model system was greater than $10 \mathrm{cfu} \mathrm{ml}^{-1}$ (data not shown). When Pseudoalteromonas TG15-07 was used at 2 concentrations (infection experimentExpt 5), bacterial concentrations were monitored until termination of the experiment. Even when added to only $5 \times 10^{2} \mathrm{cfu} \mathrm{ml}^{-1}$, levels rose to a peak of in excess of $1 \times 10^{6} \mathrm{cfu} \mathrm{ml}^{-1}$ within $3 \mathrm{~d}$ of addition and remained at this level until the end of the experiment. In all cases where presumptive TG15-07 reisolates were tested for their continued ability to inhibit $V$. anguillarum 91079 in vitro, they retained their inhibitory properties.

\section{First-feeding infection experiments (Expts 7 to 8)}

Fig. 3, which combines data from Expts 7 and 8, shows that Artemia loaded with a range of bacterial isolates, including a turbot larval pathogen Vibrio splendidus DMC-1, did not inhibit the start-feed response in Atlantic halibut. There were no significant between-experiment or between-treatment differences in the average start-feed response or in the average number of surviving larvae, whether the data from each experiment was treated separately or combined. The generally observed response was of a good uptake onto feed by Day 4 of the experiment, independent of treatment. However, the water quality and general condition of the larvae later deteriorated. By the end of the experiment (Day 8), the few flasks containing larvae with guts packed full of Artemia were generally confined to the control or OF2-05 treatments (data not shown). All the controls were contaminated with a range of non-TCBS-culturable organisms by the end of the 2 experiments.

\section{Water quality}

Total ammonia, nitrite and nitrate water measurements were taken from selected flasks at the end of all the experiments. Levels of ammonia were below $0.25 \mathrm{mg} \mathrm{l}^{-1}$. Nitrite and nitrate levels were less than $0.1 \mathrm{mg} \mathrm{l}^{-1}$.

\section{DISCUSSION}

Atlantic halibut are a good model for analyzing the effects of bacteria on larval development and survival under microbially controlled conditions. Their eggs are resistant to an aggressive disinfection protocol and high apparent rates of sterility could be obtained at the end of the yolk-sac absorption phase, as assessed by

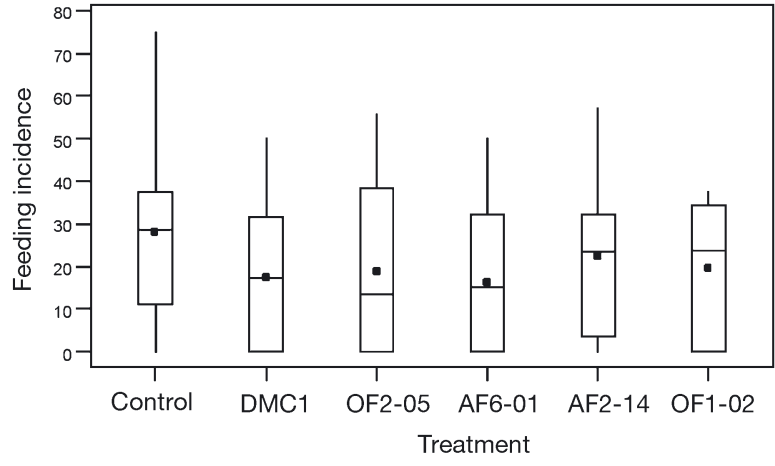

Fig. 3. Hippoglossus hippoglossus. Box plots of average \% first-feed incidence of larvae fed gnotobiotic Artemia colonized with a range of different Vibrio isolates. Results are pooled from the infection experiments, Expts 7 and 8. Central horizontal line in each box is the median; squares are mean values. Horizontal boundaries above and below the box are the 1st and 3rd quartiles; whiskers show the within-treatment range in feeding incidence. Number of samples analyzed for each treatment group was 12 , except for OF2-2 $(n=60)$ and the controls $(n=19)$

inoculating water samples into MB. For the control treatments, survival through yolk-sac absorption $(>50 \%$ ) and average start-feed response $(21.1 \%$ for the 2 experiments) were within the range encountered in commercial hatcheries. This indicates that the axenic flask-rearing model may also be useful for investigating parameters such as water quality, temperature and salinity, particularly as the variable factor of the microbial population is removed.

A high rate of deformities in the larvae was observed in all the treatments, whether bacteria were present or not (data not shown). It has been speculated that the lockjaw deformity, commonly observed in halibut hatcheries, may result from bacterial infection (Morrison \& Macdonald 1995), but since we found this condition in larvae in flasks which appeared bacteria-free, as assessed by both DAPI-stained direct counts and inoculating water samples into $\mathrm{MB}$, it does not appear to be due to bacteria. A further condition often observed in the hatcheries, in which larvae acquire opaque patches in the intestinal cavity ('white gut') at the end of their development, was also observed in some of these apparently bacteriologically sterile control flasks (results not shown). This indicates that it too does not have a bacterial cause and demonstrates the value of model systems in helping to isolate the cause of specific conditions. Although it is possible that the aggressive disinfection regime may have contributed to the high deformity rate, it was within the range experienced by hatcheries. To test this further, experiments could be done to test the effect of different handling and disinfection regimes on the deformity rate. 
Munro et al. (1995) challenged turbot larvae with a range of bacterial isolates under monoxenic conditions, and none of the bacteria tested appeared to be very pathogenic, with the exception of Vibrio anguillarum 91079. Similar results were found here (Table 2), and most of the bacteria introduced into flasks at a low initial inoculum were present at levels in excess of $10^{5} \mathrm{cfu} \mathrm{ml}^{-1}$ by the end of the experiments. Thus, yolk-sac larvae appeared to be generally unaffected by high densities of culturable bacteria isolated from different halibut rearing systems. Bergh et al. (1992) found that Vibrio species other than $V$. anguillarum can be pathogenic towards Atlantic halibut yolk-sac larvae. Also, in commercial-scale rearing trials it was noted that there were correlations between the survival of yolk-sac larvae and the presence, or absence, of particular bacterial isolates (Verner-Jeffreys 2000). However, none of these isolates appeared to be very pathogenic when tested individually against larvae in the model rearing system and when compared to $V$. anguillarum. The results on $V$. anguillarum pathogenicity are in agreement with previous infection studies (Bergh et al. 1992, Bricknell et al. 2000). Bergh et al. (1992) used a different challenge strain (NCIMB 6, which was originally isolated from cod) and a higher inoculum (2 to $3 \times 10^{6}$ organisms $\mathrm{ml}^{-1}$ $2 \mathrm{~d}$ before the eggs hatched, as opposed to $5 \times 10^{2}$ to $1 \times 10^{3}$ organisms $\mathrm{ml}^{-1} 4 \mathrm{~d}$ after hatch). It was interesting that in trials where the larvae had presumably been invaded and killed by $V$. anguillarum it was not readily isolated from the flask water, even at the termination of the experiments. Munro et al. (1995) showed that $V$. anguillarum was present at very low levels in heavily inoculated flasks containing turbot larvae until periods of high mortality, which presumably coincide with infected larvae shedding the pathogen into the water. These results together reinforce speculation (Enger et al. 1990) that certain $V$. anguillarum serotypes are specialized invasive pathogens that are not well suited to a free-living aquatic existence.

Larval mortalities were not noticeable until late in development (Fig. 2). This could have been a temperature-related effect, with the pathogen multiplying slowly inside the larvae at the low rearing temperature $\left(6^{\circ} \mathrm{C}\right)$ used in this study. Alternatively, the larvae may be resistant early in their development, but when their maternally derived host defences are exhausted they may then become more susceptible to invasion.

There was a wide range in the percentage survival of larvae within treatments (Fig. 1), often irrespective of treatment. This was particularly noticeable in Expt 2, where survivals in the control flasks varied between 0 and $88 \%$. Culturable bacteria were only isolated from one of these flasks, so a bacterial etiology is unlikely, particularly as water samples from 1 flask which had no surviving larvae appeared bacteriologically sterile by DAPI staining.

The high intra-treatment variation in survival observed could have masked possible treatment effects. However, observed mortalities in the hatcheries are often catastrophic, suggesting that, if the mortality events are caused by bacteria, similarly high mortality rates would be reproduced by the responsible organisms in the flask-rearing system. It is possible that mortalities in the flask-rearing system were caused by a viral agent present in some of the eggs, despite the aggressive surface-disinfection procedure. However, in one experiment, moribund larvae from one 'crashing' flask were transferred to flasks containing sterile freshly hatched larvae, but no mortalities ensued in larvae in these flasks (data not shown). Although this does not rule out the possibility that a transmissible agent was responsible for the mortalities, it lessens the likelihood that this was the cause.

The results of the probiotic addition experiments show the importance of testing organisms showing in vitro promise in small-scale model experimental systems first, before committing substantial resources to field experiments. However, Vibrio anguillarum is a particularly virulent fish pathogen and may be an inappropriate test pathogen for such experiments. Strains TG15-07, AN1, AN2 and other probiotic candidates may confer protection against other pathogens such as Flexibacter ovolyticus (Bergh et al. 1992) or less specialized, opportunistic pathogens that, it has been speculated, may be a greater problem in marine hatcheries (Vadstein et al. 1993, Skjermo et al. 1997, Hansen \& Olafsen 1999, Ringo \& Birkbeck 1999). However, as indicated here, the inability to isolate readily obvious bacterial pathogens indicates that even 'opportunistic' pathogens may be rare components of the hatchery microbiota.

Poor, or variable, start-feeding rates have been commonly reported by commercial Atlantic halibut hatcheries (Shields et al. 1999) and the data presented here suggest that bacterial contamination of the live feed is unlikely to be the major cause of this problem. Accordingly, research efforts may be better focused on other potential biological and environmental causes, such as the tank environment, as a way of resolving this key bottleneck. However, live-food-associated pathogenic micro-organisms do seem to cause serious mortalities in turbot after the larvae have initiated feeding (Gatesoupe et al. 1999). Axenic larvae flask rearing models might be usefully deployed in determining the cause of such losses in Atlantic halibut and other cultured marine fish. 
Acknowledgements. This study was funded by the British Marine Finfish Association (formerly known as the British Halibut Association) and MAFF/LINK FIN22 project 'Rearing protocols for Atlantic halibut larvae during transition from endogenous to exogenous feeding'. We thank Berit Adam for technical assistance. Eggs for the infection experiments were kindly supplied by Otter Ferry Seafarms, Argyll, Scotland.

\section{LITERATURE CITED}

Bergh Ø, Hansen GH, Taxt RE (1992) Experimental infection of eggs and yolk sac larvae of halibut, Hippoglossus hippoglossus L. J Fish Dis 15:379-391

Bergh Ø, Hjeltnes B, Skiftesvik AB (1997) Experimental infection of turbot Scophthalmus maximus and halibut Hippoglossus hippoglossus yolk sac larvae with Aeromonas salmonicida subsp. salmonicida. Dis Aquat Org 29:13-20

Bricknell IR, Bowden TJ, Verner-Jeffreys DW, Bruno DW, Shields RJ, Ellis AE (2000) Susceptibility of juvenile and sub-adult Atlantic halibut (Hippoglossus hippoglossus L.) to infection by Vibrio anguillarum and efficacy of protection induced by vaccination. Fish Shellfish Immunol 10: $319-327$

Enger Ø, Husevag B, Goksøyr J (1989) Presence of the fish pathogen Vibrio salmonicida in fish farm sediments. Appl Environ Microbiol 55:2815-2818

Enger $\varnothing$, Hoff KA, Schei GH, Dundas I (1990). Starvation survival of the fish pathogenic bacteria Vibrio anguillarum and Vibrio salmonicida in marine environments. FEMS Microbiol Ecol 74:215-220

Gatesoupe FJ (1999) The use of probiotics in aquaculture. Aquaculture 180:147-165

Gatesoupe FJ, Lambert C, Nicolas JL (1999) Pathogenicity of Vibrio splendidus strains associated with turbot larvae, Scophthalmus maximus. J Appl Microbiol 87:757-763

Gram L, Melchiorsen J, Spanggaard B, Huber I, Nielsen TF (1999) Inhibition of Vibrio anguillarum by Pseudomonas fluorescens $\mathrm{AH} 2$, a possible probiotic treatment of fish. Appl Environ Microbiol 65:969-973

Hansen GH, Olafsen JA (1999) Bacterial interactions in early life stages of marine cold water fish. Microb Ecol 38:1-26

Haug T (1990) Biology of the Atlantic halibut Hippoglossus hippoglossus (L. 1758). Adv Mar Biol 26:1-70

Editorial responsibility: David Bruno, Aberdeen, UK
Horne MT, Richards RH, Roberts RJ, Smith PC (1977) Peracute vibriosis in juvenile turbot Scophthalmus maximus. J Fish Biol 11:355-361

Lein I, Holmefjord I, Rye M (1997) Effects of temperature on yolk sac larvae of Atlantic halibut (Hippoglossus hippoglossus L.). Aquaculture 157:123-135

Morrison CM, Macdonald CA (1995) Normal and abnormal jaw development of the yolk sac larva of Atlantic halibut Hippoglossus hippoglossus. Dis Aquat Org 22:173-184

Munro PD, Barbour A, Birkbeck TH (1995) Comparison of the growth and survival of larval turbot in the absence of culturable bacteria with those in the presence of Vibrio anguillarum, Vibrio alginolyticus, or a marine Aeromonas sp. Appl Environ Microbiol 61:4425-4428

Ottesen OH, Bolla S (1998) Combined effects of temperature and salinity on development and survival of Atlantic halibut larvae. Aquacult Int 6:103-120

Ringo E, Birkbeck T H (1999) Intestinal microflora of fish larvae and fry. Aquacult Res 30:73-93

Shields RJ, Gara B, Gillespie MS (1999) A UK perspective on intensive hatchery rearing methods for Atlantic halibut (Hippoglossus hippoglossus L.). Aquaculture 176:15-25

Skjermo J, Vadstein Ø (1999) Techniques for microbial control in the intensive rearing of marine larvae. Aquaculture 177:333-343

Skjermo J, Salvesen I, Øie G, Olsen Y, Vadstein Ø (1997) Microbially matured water: a technique for selection of a non-opportunistic bacterial flora in water that may improve performance of marine larvae. Aquacult Int 5: $13-28$

Smith P, Davey S (1993) Evidence for the competitive-exclusion of Aeromonas salmonicida from fish with stressinducible furunculosis by a fluorescent pseudomonad. J Fish Dis 16:521-524

Vadstein Ø, Øie G, Salvesen I, Skjermo J, Skjak B (1993) A strategy to obtain microbial control during larval development of marine fish. In: Dahle LA, Jorgensen L, Reinertsen $\mathrm{H}$, Tvinnereim $\mathrm{K}$ (eds) Fish farming technology. AA Balkema, Rotterdam, p 57-58

Verner-Jeffreys DW (2000) The bacteriology of Atlantic halibut. PhD thesis, University of Glasgow

Verner-Jeffreys DW, Shields RJ, Bricknell IR, Birkbeck TH (2003) Changes in the gut-associated microflora during the development of Atlantic halibut (Hippoglossus hippoglossus L.) larvae in 3 British hatcheries. Aquaculture 219:21-42

Submitted: November 5, 2002; Accepted: May 16, 2003 Proofs received from author(s): August 25, 2003 